\title{
Investment in Financial Derivatives Contracts from an Islamic Perspective
}

\author{
Dr. Yaser Abdel Karim Mohammed Hourani \\ Associate Professor of Islamic Economics \\ Faculty of Administrative \& Financial Sciences \\ University of Albaha / Kingdom of Saudi Arabia \\ E-mail: yaserhorani@yahoo.com
}

Dr. Mohammed Ali ZARAI

Associate Professor of Financial Accounting

Faculty of Administrative \& Financial Sciences

University of Albaha / Kingdom of Saudi Arabia

E-mail: zaraimedali@yahoo.fr

\author{
Received: March 2, 2014 Accepted: March 25, 2014 Published: April 18, 2014 \\ doi:10.5296/ifb.v1i1.5442 URL: http://dx.doi.org/10.5296/ifb.v1i1.5442
}

\begin{abstract}
This research aims at exploring the nature of financial derivatives (FD) and their associated activities, and thus highlight their legitimate rule from an Islamic Perspective. Although there are many kinds of financial derivatives, this research focuses on the discussion of only three basic contracts; namely options, futures and swaps contracts, because they represent financial contracts derived from financially stable instruments such as stocks and bonds. There is no doubt that the great importance of this research lies mainly in determining the nature of these contracts and knowing their legitimate rules.

In dealing with this issue, the research employs a descriptive approach which relies on first clarifying the image of each contract and its contemporary concept, second explaining the contract's performance and applications in the field of financial transactions, with reference to illustrative examples, and finally discussing its legitimate rule.

The research results in uncovering the legitimate ruling on financial derivatives contracts, summed up mainly in the presence of betrayal and ignorance; leading, therefore, to the
\end{abstract}


prohibition of such contracts.

Keywords: Options, Swaps, Futures, Derivative contracts, Islamic perspective 


\section{MInstitute ${ }^{\text {Mnk }}$}

\section{Introduction}

Islamic Financial derivatives contracts are considered to be newly introduced formulas in the field of financial investment. They represents a set of financial instruments derived from other investment tools, such as stocks and bonds; this means that they derive their value from the value of the other tools. With such a description, financial derivatives gain a great importance in the funding purposes; they also meet the objectives of investors in the capital markets in order to face price fluctuations, known as hedging. Moreover most of the investors use these tools in the area of fast speculations to collect the profits that result from the difference between the value of the underlying securities and the market prices.

There were various studies in the field of financial investment which dealt with financial derivatives but without any serious attempt to uncover the truth of their related activities, especially their Islamic ruling. This research has also benefited from the basic concepts of derivatives introduced in so many literatures. Among them we may mention a study by Fayyadh Attia (1998) entitled "The Stock Market in the Balance of Islamic Jurisprudence," the study of Mohammed Ahmed Saad (2008) entitled "Contemporary Financial Markets" and the study of Mohammed Ali Al-Quary (2010) entitled" Financial Markets". We may also mention the decisions of the Council of Islamic Jurisprudence emanating from the Organization of the Islamic Conference in Jeddah in its seventh session (1992).

The research aims at stating a number of issues related to financial derivatives, of which the most important are:

- uncover the truth of contemporary financial transactions within the scope of derivatives trading,

- provide a simplified picture of the actual applications of the derivatives prevailing in the financial market,

- clarify the Islamic ruling on the commercial work in the field of financial derivatives.

The research methodology is based on the inductive analytical approach of the data in question. It is carried out through the collection, discussion, analysis and presentation of the data required in a simplified way to infer its Islamic ruling.

This research includes an introduction, three sections and a conclusion. The first section deals with options contracts (Options) in terms of concept, characteristics and types; and thus access to their legitimate rule. The second section discusses futures contracts (Futures), their concept and types within the scope of the capital and the monetary markets; then deduce their legitimate rule and state the difference between them and some other contracts such as Forwards and Options. The third section focuses on swap contracts (Swaps). It aims mainly at providing the definition of those contracts with reference to their different types, such as interest and exchange rates swaps, returns securities swaps, and goods swaps, and then discuss the legitimate rule of each type separately. 


\section{Macrothink}

\section{Option Contracts}

Option contracts are considered as among the basic tools that affect the market relations. They depend on the prediction of price changes, and differ in this aspect from the option contracts known in Islamic jurisprudence. This section is trying to clarify the reality of these kinds of contracts, their types and their legitimate rule within the realm of three main requirements. The first requirement: the concept and the characteristics of option contracts. The second requirement: types of option contracts. Third requirement: the legitimate rule on option contracts.

\subsection{The Concept and the Characteristics of Option Contracts}

\subsubsection{The Meaning of Option Contracts}

The option contract is defined as a "contract through which the contract editor gives the buyer of that contract the right to buy or sell something at a specified price, during a certain period of time, or on a specific date" (Hammad, 2003). It is also defined as a "substitute contract on an abstract right that entitles its owner to buy or sell something at a specified price, for a certain period of time, or on a specific date, either directly or through a committee that guarantees the rights of the two parties" (the Islamic Fiqh Academy, No. 7) .

So, this contract can be defined as a choice between several alternatives; for example, in the stock market, this right is exercised to buy or sell stocks, and the value of the option contract will be derived from the original securities (Mayo, 1997).

It is clear that the option gives the owner a right in exchange for the payment of a financial reward. In other words, by not benefitting from this right in the given period of time, the owner of the option will be subject to a loss as equal as the bonus paid.

It should be noted that there exists some kind of relationship between the option contract and short selling depending on the kind of transaction. In fact, in the case of purchasing, the traders in financial markets, and as they expect an increase in prices, would normally opt for the option contract; however, in the case of selling, and if they expect the price to drop down, they would buy the put option being thus similar to short selling. In this case, the put option will be an alternative to short-selling, and having the same effect on price levels.

There are some other uses of the option contract, such as the hedging or the insurance processes. However, the real danger behind option contracts lies in the negative consequences that accompany them, and which bring about significant effects on the relations of the capital market as well as the prices levels.

\subsubsection{Characteristics of Option Contracts}

The most important characteristics of option contracts can be identified in the following points:

- $\quad$ Flexibility

The right of option gives its owner the flexibility to move in the market, because he does not 


\section{Macrothink

deal with specific stocks, but rather with the right to possess or sell shares (Al Solomon, 2005). This may perhaps explain why the owner of the right of option would not investment in the stocks of particular companies.

- Obligation

The option contract consists of a vendor and a buyer of the right of option. It is binding to the vendor but not to the buyer (Fayyad, 1998).

- $\quad$ Option reward

The right of option depends on the existence of a non-refundable reward or a price for the option (bonus) that the seller provides to the buyer.

The option reward depends on several factors that determine the price level at the implementation, such as the duration of the contract, the type of asset, the investment environment in the capital and monetary market (Balboul, 1992), and the degree of risk.

- $\quad$ Term

This means that the implementation of the option is done at a given period of time or at a specific time. In all cases, the buyer of the option will be able to make some profit only if that same option is sold during or after the given interval of time at a favorable price, that consists of the difference between the strike price and the market price of the traded shares (Khryosh, 1998).

- $\quad$ Trading

The right of option can be traded in the capital markets. This would make of the right of option a valueless derivative financial paper that derives its value from the traded security (Fayyadh, 1998).

\subsubsection{Comparison between Option Contracts and Choice Contracts}

The option contracts defined above differ from the choice contracts included in the jurisprudence of financial transactions according to the following points:

- Option contracts are derived from the capitalist system, which aims at maximizing profits in various ways; whereas, choice contracts represent one of the basics of Islamic jurisprudence economy.

- Option contracts give the owner the right to buy or sell shares, whereas choice contracts aim at finding a legitimate right for each of the contractors to sign or terminate the contract, and thus achieve mutual satisfaction.

- Option contracts are signed for a valuable compensation paid by the benefiter of the right of buying or selling. The payment of that compensation aims at transferring the risk from one party to another at times of price drop, or achieving expected profit; whereas choice contracts are done without any compensation.

- The right of option is a salable and a purchasable commodity between the dealers in the 
capital markets, where the broker plays the role of a financial intermediary. However, the right of choice is not a market commodity; it is rather concluded in the contract council, and can be terminated with the will of one of the contracting parties.

\subsection{Types of Option Contracts}

Option contracts are of three main types, and each type has a special nature that distinguishes it from the others, namely:

\subsubsection{Call Option Contract}

A call option contract is defined as an agreement between two parties through which the first party, called the editor or the seller of the contract, gives the other party the right to choose between buying a particular asset or not at a specified date and price (Hammad, 2003). It is clear that the call option contract consists of a vendor of the right of option (Contract Editor), a buyer of the right of option, and the price of the option paid by the buyer to the vendor at a predefined time. Moreover, the subject of the contract is an asset that takes the form of goods already decided by the contractors. However, with the development of financial markets, it has become a larger pot which includes securities such as stocks, bonds, foreign currencies and stock price indexes (Hanafi, 2003).

Both the buyer and the vendor aim at protecting themselves from the risk of price fluctuations, in the so-called the "hedging" process. In this case, the expectations of prices change will be different for both contractors; that is to say, the buyer is expecting the prices to rise, while the seller is expecting them to lower. However, the primary goal sought by the buyer of the option in contemporary financial transactions is to achieve profits through "speculation", and differences in prices; while the seller gets the option reward. All call options can be applied in the capital as well as the monetary markets, including the foreign exchange market.

[See illustrative example (call option contract) Appendix 1]

\subsubsection{Put Option Contract}

The put option contract is defined as an agreement between two parties through which the first party, called the editor or the seller of the contract, gives the other party the right to choose between buying a particular asset or not at a specified date and price (Hammad, 2003). The pillars of this contract are the same as the pillars of the "Call option" contract. But the owner of the option is a seller not a buyer, and is called the option buyer, while the other party is called the option vendor. The option buyer seeks to hedge against the risk of lower prices, and tries to speculate to take advantage of price differences. The vendor of the option, however, aims at getting the option reward.

Hence, the seller's (option editor) attitude whether to edit a "Call option" or a "Put option" will be determined in the light of the market data. So, if he had expectations of higher prices, he would edit a "Put option"; whereas, he would tend to favor a "Call option" at times of lower prices expectations. And in both cases, the other party will neither be able to sell in the case of "put option" because the market value is higher than the implementation price, nor to purchase in the case of "Call option" because the implementation price is higher than the 
market value. Therefore, the seller (option editor) would gain a profit in the form of option reward. However, the risk in such investment emerges when the seller's expectations of a change in prices wouldn't be fulfilled, subjecting him, thus, to a loss equivalent to the difference in prices. As a result, the option editor would tend to deal in the financial market when it is in a state of relative stability, contrasting, thus, the other party whose expectations are mainly based on the likelihood of sudden swings in the market.

\subsubsection{Double Option Contract}

The double option contract combines both the "Call option" and the "Put option"; as such the holder of the option is entitled to be a buyer or a seller of the same financial asset. In this case, the holder of the option would buy if the implementation price is less and would sell if it is higher than the prices level. On the contrary, the editor of the option would face higher risks which would lead to an agreement to increase the option reward (bonus) (Radwan, 1996).

This type of option contracts brings forth profits to its holder when the market is witnessing sudden and great swings in prices levels. As a result, the holder of the option pays a high reward because he has expectations of abrupt price changes. So, if the prices rise up he would carry out a "call option", in which his profits will be achieved through the difference between the implementation price, at which he has already bought, and the high market price, at which he is now selling. But if the prices fall down, he would implement a "put option", gaining, thus, profits from the difference between the implementation price, at which he has already sold, and the low market price, at which he is now buying. All this cannot be fulfilled unless his predictions are correct; otherwise, he won't perform any operation and bear the loss in the form of the option reward (Hamami, D. T.).

From this contract, we can also devise other forms that vary according to the difference in some of their criterion. For example, the holder of the option can combine between a "call option" and a "put option", and, unlike the previous case, be a buyer and a seller at the same time. This type of dual contracts is called "Straddle". There are also other kinds of dual contracts such as "Strip", in which the holder of the option combines between three contracts; two options for selling and one for buying.

\subsection{Legitimate Rule on Option Contracts}

The legitimate rule on the financial operations done through options contracts enter in the realm of forbidden exchanges (Islamic Fiqh Academy, No.7), for many reasons, including:

- Option contracts involve the existence of betrayal and ignorance because the subject of the contract is neither money nor a benefit or a financial right that might be compensated for (Fayyad, 1998). In fact, the contractor does not know the role he plays in such an investment; i.e. he doesn't know whether he is a seller or a buyer, resulting, thus, in some kind of betrayal. As for ignorance, it results from the fact that none of the contractors knows the amount of the sale stated in the contract.

- These contracts give more chance to one of the contractors because of his ability to get access to information about market prices as well as the influential factors that may move 


\section{Macrothink

the prevailing prices downward or upward. Among those factors we may mention the breaching of the confidentiality of the decisions taken by the company's management board, dividend policies, the increase in the company's capital, the granting of the shares, and any information that may influence the demand and supply with regard to the size of the traded shares.

- Option contracts include corrupt conditions which are contrary to the requisites of the contract because they are based on the establishment of a new contract that includes an increase in the amount of the original sale (Al-Bahooti, 1997). As a result, the selling of the option may be considered as an act of a "two transactions in one".

- The corrupt condition also includes the presence of a reward (bonus) that exceeds the real compensation. This reward is paid for the right of option, being thus, similar to forbidden interest because it is an unjust increase (Ibn Al-Hamam, D. T.). Here, it must be noted that the reward cannot be paid in return for the commitment of one of the contractors to sell something specific because the contract itself refers to a reward granted for a right. In addition, the commitment cannot achieve its meaning only after the expiration of the contract which is not the case here because it is just an implicit pledge part of the contract content.

- Option contracts may be considered as an act of selling what one does not own. As a result, they have been prohibited because they are sham contracts that do not even refer to any kind of ownership. In fact, the contractor on the right to buy the shares is not interested in the ownership of those shares as much as the acquisition of a given balance of stocks at the broker. This process may often end by the selling of the right of option through market dealing.

- Option contracts contribute to the instability of the market because the objectives and the conditions that accompany them are not intact. They also remain suspended in wait for the prices to increase, unlike the legitimate option contract which is finalized with the ratification of the contract.

- Most importantly, option contracts tend to be similar to forbidden gambling, as is the case with short-selling. This results from betrayal, with which the rights are denied. Moreover, gambling involves a risk to get the compensation (Ibn Taymiyyah, 1995). Although the objection to such inference may be based on the fact that gambling is caused by real betrayal, while in option contracts the betrayal is not real because the contractors have enough financial and technical expertise to know market trends, this objection can be counterfeited by the fact that in this case we have a winner and a loser, and who loses cannot be considered as a man of knowledge and expertise.

- Some contemporary scholars have also linked between option contracts and forbidden commercial insurance. The similarity between them consist in the compensation paid for a potential risk, which is, in fact, another form of betrayal (Al-Quary, 1995). 


\section{Macrothink}

- Option contracts also reflect, in their essence, the nature of the bets which aim at getting in and out of the market as quick as possible. There is no doubt that the dealers in option contracts enter into a game of speculation to reach the expected prices. This way, speculation differs from the legitimate speculation as stated earlier, because of the presence of pressure forces and interest groups operating within the market to control prices.

\section{Futures Contracts}

Futures contracts represent one of the newly devised images in the field of finance. They are examples of financial derivatives that derive their value from the assets they represent. They also strongly intermingle with speculation on the basis of the expectations of changes in market prices. This section illustrates the reality of futures contracts, their types and their legitimate rule in the light of the following four requirements. The first requirement: the concept and the significances of futures contracts. The second requirement: types of futures contracts. Third requirement: the legitimate rule on futures contracts. Fourth requirement: comparison between futures contracts and some other contracts.

\subsection{The Concept of Futures Contracts and Their Significances}

\subsubsection{Meaning of Futures Contracts}

Futures contracts are simply defined as contracts implemented at a later period of time. The implementation of all the requirements, that are binding to both contractors, must be taken into account. Based on that, futures contracts are defined as an agreement to exchange financial instruments, through buying or selling, for specific terms and conditions with the delivery of both the article and the price at a specified future date (Hanafi, 2003); or it is a contract between two parties, one is a seller and the other is a buyer, for the purpose of delivering an asset at a later date and particular price (Hanafi, 2002). They also aim, like other contracts, to face price fluctuations as well as quick speculations (Awadh, 1988). Moreover, the investor in this kind of contracts has to deposit an initial margin at the brokerage firm; and if this margin goes down, he will deposit another margin, the so-called prevention margin.

\subsubsection{The Implications of the Concept}

From the definition, we can highlight the most important implications concerning the meaning of futures contracts, namely:

- Terms of the contract: The contractors agree on all the conditions required in the exchange process such as the type of goods subject of the contract (i.e. the physical commodities and the financial assets represented by bonds), money market indicators, foreign exchange, and treasury bills.

- Implementation of the contract: Although the implementation of the futures contracts is delayed for a later time, they are legally binding in the sense that none of the contractor is 
allowed to breach the implementation of the agreement.

- Exchange parties: There are three exchange parties in the futures contracts, namely the buyer, the seller, and the brokerage. Both the buyer and the seller have the desire to buy and sell with no obligation to meet. As for the brokerage system, it plays an active role in determining the contract terms and conditions for the contractors within different alternatives. It receives a commission in return for the creation of the contract and the follow up of its implementation. It also takes all the necessary administrative and technical measures, known as stereotype contracts (Ramadan, 1998).

\subsection{Types of Futures Contracts}

There are several types of futures contracts that can be classified on the basis of the market to which they belong, i.e. the capital market and the money market. In fact, each market can accommodate many types.

\subsubsection{Capital Market}

The capital market includes all futures contracts which deal with material goods as well as assets or financial instruments. As for physical commodity contracts, they include all the goods that are consistent with the provisions of trade. That is to say, the goods must be apt to specification in terms of description, amount, type, quality, and size.

Here it should be noted that the physical commodities must be savable, because what cannot be saved may not meet the maturity date. Moreover, the responsibility for determining the commodity standards in this clause falls on the brokerage system known as the "House of Settlement" (Obaid, D. T.). This body would check the traded goods and guarantee the intactness of their properties till the time of their handover.

As for financial instruments contracts, they include securities such as stocks and bonds. They also deal with significant financial instruments, such as stock exchange indexes, which clearly reflect the nature of the financial market. They are also the most interesting financial instruments for the investors, and continuously affect the making of investment decisions and help in measuring the level of financial activity in a particular market.

There are several indexes such as "Index indicator", which uses preferential weights of prices through market values for the comparison and the foundation period; and the "New York Stock Exchange index", which measures the change likely to happen in the total market value; and the "Standard and Poor's index (S\&P)", which is extracted by dividing the total value of the current stock market prices on its total value in the year of basis, and it consists of 500 companies holding only one share each; and the "Nasdaq Composite index." There are also many other indexes of which we can mention the "Dow Jones Islamic Market Index", and Dubai's index "DFM General Index".

The profits in dealing with the indexes are calculated on the basis of the difference between the purchase price and the value of the index at a specific period of time. For example, the profits would be counted in favor of the buyer, if the purchase price is less than the index value at maturity; whereas, it would be counted in favor of the seller, if the purchase price is 


\section{Macrothink}

higher; and the settlement between the contractors occurs in the form of a cash swapping, free of any financial asset handover (Al Qari, 1995).

\subsubsection{Money Market}

The money market includes the futures contracts that are interested in currencies exchange. In these kinds of contracts, currencies swaps occur according to their exchange rates resulting from the forces of supply and demand, which are basically affected by quick speculations. The traded currencies are generally global currencies such as the euro, all types of dollar, the Japanese yen, the pound sterling, and others.

The futures contracts in the field of currencies aim to achieve big goals for the dealers in the money markets, especially those interested in transitory trade between the countries. It is in fact well known that the rapid change in the price of world currencies would not only affect the actual costs of trade between the countries, but it would also have direct effects on the strategic objectives of the economic plans on a national scale. Hence, dealing with futures contracts in the money market is of a great importance for the role they play in maintaining a relative economic stability, and preventing any financial losses resulting from the change in foreign currencies exchange rates. According to that, the dealers with futures contracts will try to monitor the prices of currencies and conclude the contracts to hedge against sudden cash fluctuations.

[See appendix 2 (illustrative example: futures contracts)]

\subsection{The Legitimate Rule on Futures Contracts}

The scholars have discussed in their jurisprudential works some flaws that would lead to the prohibition in financial transactions, and would help in devising the legal judgment in such innovative contracts. It is clear that the legitimate rule on the issue of futures contracts is strict prohibition (Dagi, Jurisprudential Academy Journal, No. 7). This statement can be generally outlined from different perspectives, of which the most important are:

- The delay of both allowances, the price and the appraised, indicates that this type of contracts is more like the selling of a debt for debt, deemed to be one of the forbidden sales. This includes all the forms where futures contracts are used.

- Riba al-nasee'ah (usury) happens in such contracts if the traded articles are gold or silver against the securities, for the total agreement between them in the prohibition defect, i.e. the preciousness (Ibn Qudamah, 1992); and in the prophetic tradition, "If these types are different, sell as you wish, on the condition it is a hand to hand selling".

- These contracts embody the meaning of forbidden gambling because each of the contractors is prone to be a winner or a loser at the expense of the other. This situation clearly manifests itself at the settlement and the distribution of profits and losses on the basis of price differences, which intermingles with the meaning of gambling.

- The fact of "selling what one doesn't own", is also manifested through futures contracts, because they are originally based on the delaying of the allowances, entering thus under 
the rule of general prohibition, as stated in the previous prophetic tradition "Do not sell what you do not have".

- All contractors lurk fluctuations in the level of prices. This means that futures contracts will be strongly connected to speculations that affect the market relations and lead to the occurrence of economic oscillations, inconsistent with the interest of the group.

- With regard to indexes contracts, however, the Islamic Fiqh Academy issued a fatwa that "no one shall sell or buy an indicator, because it is pure gambling, and a sale of a fanciful thing devoid of any existence" (the Islamic Fiqh Academy, the seventh session, 1992). It is clear that dealing with these contracts may be considered as a sort of gambling for the mere reasons that they have a winner and a loser, each at the expense of the other, and the article subject of the contract is something fanciful. On the other hand, the index bowl includes a large number of different investment tools, which are owned by more than one company. This, in return, results in the ignorance of the article's kind and amount, which cannot be described or disclosed through the calculations of the index record.

\subsection{Comparison between Futures Contracts and Other Contracts}

\subsubsection{Comparison between Forwards Contracts and Futures Contracts}

We can devise some of the differences between forwards and futures contracts. This is done according to their concepts and specific criteria, as per the following points:

- $\quad$ Nature of the market: In futures contracts, the market takes a stereotyped form that goes beyond the interactive relations between the exchange parties, because it takes place in an organized trading market; this case is different from forwards contracts that depend on the contractors' decisions through mutual negotiations and interactive relationships.

- Contract rating: Futures contracts are classified as financial derivatives contracts, because they are subcontracts based on essential ones, and deriving their values from the prices of the original investment tools. Forwards contracts, however, are not included in derivatives contracts because they reflect the real prices of the traded assets, and are not derived from other contracts.

- Price change: Futures contracts are affected by the price change over the time period of the contract which will in return affect the movement of profits and losses between the contractors; however, the price in forwards contracts is fixed until the end of the contract (Hammad, 2003).

- Settlement: The price movement in futures contracts are settled on a daily basis, which means that the cash flow in these contracts would be of short-term, and the leveling would be done through a follow-up mechanism of the change in price and link it to a margin appropriate with the value of the swap. In forwards contracts, however, the effectiveness of the settlement system results in the need for a guarantor body in charge of all the required procedures, such as the estimation of the daily price differences, margin calculations, and the representation of both parties in their continuous contracting relations. 


\section{Macrothink}

- The diversity of the contract: Forwards contracts lack the existence of various forms in contrast with the diversity in futures contracts. And as stated earlier, futures contracts tolerate the existence of many types of contracts such as definite futures, futures with the condition of termination and compensation option, multiple futures, and other.

- Delivery of the asset subject of the contract: Futures contracts focus on the derivative nature of the subcontracts and the changing prices. These contracts often end without handover of the asset subject of the contract to the buyer, because they enter into new contracts. On the contrary, forwards contracts expire with the transfer of the investment instruments subject of the contract from the buyer to the seller at the maturity date.

- Risk: The risk in futures contracts is insignificant. Each of the contractors would have the right, all along the time period of the contract, to go through a counter process to sell or buy in order to create a new contract. However, this case is not possible with forwards contracts, unless they are accompanied by the renunciation option to the buyer, or the termination option for each of them for a compensation that differs with the variation of the contract.

\subsubsection{Comparison between Futures and Option Contracts}

Some of the differences between futures and option contracts may be clarified through the following points:

- Commitment: The responsibility to abide by the accomplishment of the contract in futures contracts falls on both contractors. But in the case of option contracts, the buyer would have sufficient flexibility with regard to the accomplishment of the contract which is not the case with the seller (editor of choice), who commits himself to the completion of the contract in the light of the buyer's desire (Hammad, 2003).

- Topic of the contract: the subject of the contract in futures contracts are the investment instruments. But in the case of option contracts, the whole operation goes around the right to buy or sell the stocks (Al Qari, 1995).

- Risk: It seems that the size of the risk in futures contracts is higher, and matches with the change in the prices of the futures contract. This means that the degree of the risk is nonspecific. As a result the investment in these contracts requires a careful study and a constant follow-up of the change in prices. However, with option contracts, the size of the risk is limited, and does not exceed the value of the option reward (bonus).

\section{Swap Contracts}

Swaps are considered as important contracts in the field of financial investment, especially because they differ from the previous kinds of derivatives contracts. In fact, these contracts are not subject to the legal conditions known in the trading process because they do not take place in a regulated market. The most important issues related to those contracts can be clarified through the following three requirements. The first requirement: the concept of swaps. The second requirement: the types of swaps. Third requirement: the legitimate rule on swaps. 


\subsection{The concept of Swaps}

There are several various definitions of swaps because they relatively vary in their nature and forms. In fact, swaps were mostly defined as representing "an agreement between two or more parties to exchange a series of cash flows during a future period" (Hammad, 2003); or as "series of contracts that are subsequently implemented and settled at periodic intervals" (Al-Henawi, 2002). Some others have defined swaps as a contractual commitment to exchange cash flow or a particular asset for another cash flow or asset with certain agreement conditions (Ramadan, 1998).

From these definitions, we can devise a set of the basic contents and criteria that may help in the understanding of swaps; the most important of which are:

- Swaps include a large bowl that makes it possible to swap interest rates, and securities, as well as the possibility to exchange goods and currencies, and so on.

- Contrary to option contracts, swaps are a sort of binding contracts to both parties. In addition, these contracts are settled on a regular rather than a daily basis as is the case with futures contracts.

- Swaps aim to manage risks, especially in the area of interest rates and currencies. In fact, the speculators always try to direct the movement of interest rates or exchange rates towards their interests, and reduce the risk of any unexpected losses.

\subsection{Types of Swaps}

Swaps accommodate many types that differ according to the nature and the form of the swap. In this part, we will state some of the most important types of these contracts, namely:

\subsubsection{Interest Rate Swaps}

It is known that any change in interest rates involves high risk that often leads to lenders' and borrowers' bankruptcy. Because of the complex nature of this issue, the idea of working with interest rate swap contracts emerged as a way to hedge against interest rates fluctuations. Indeed this process means the existence of an agreement to swap debt obligations or benefits which will achieve profit for the parties of the contract (Habash, 1998). This means that the nature of this contract is based on some essential elements such as fixed and variable interest rate, fixed and variable interest motive, the value of the swap contract and the settlement (Al-Henawi, 2002).

There are two basic types of interest rates swaps which rely on the determination of the paying and the receiving sides. The first type is a payment swap, where the first party, who expects an increase in interest rates, goes through a (paying) swap of a fixed interest rate for a variable one for a definite period of time. Whereas, the second type represents a receipt swap, through which the first party, and on expectations of lower interest rates, engages in a (receiving) swap of a fixed interest rate for a variable one at a definite time.

[See appendix 3 illustrative example: (interest rate swaps)] 


\section{MIN Macrothink}

\subsubsection{Foreign Currency Swaps}

In these contracts, the contractors swap one currency for another to take advantage of exchange rate variations. It can be defined as an agreement between two parties to swap one currency for another on the basis of the prevailing exchange rate on the conclusion of the contract (instantaneous price), and a discount that determines the difference in interest rate between the two currencies when swapped later (Trad, 2005); or it is "a contract between two parties to buy specific amounts of foreign currencies from each other, on the basis of the instant price, and sell them, on the basis of future prices" (Habash, 1998). In other words we can deduce that these contracts are a swap of one loan for another at an interest rate which differs according to the contractors' expectations.

These contracts are generally concluded in order to ensure the necessary liquidity to finance operations, or to speculate on currencies in order to achieve the dealers' interests, and thus reach the expected exchange rates at maturity. In addition, the central banks tend also to exchange currencies in order to control the amount of domestic and foreign currencies liquidity through swap operations with the local banks in a manner consistent with the monetary policy.

In this way, currencies swap is similar to what is known in economics as "Comparative Advantage" where each of the two parties needs what the other has, and so does his best to obtain from him the required benefit.

[See appendix 4 Illustrative example: (foreign currency swaps)]

\subsubsection{Securities Returns Swaps}

These contracts are similar in concept to interest rate swaps for the existence of different expectations. However, these expectations would relate to securities profits which are determined by the movement of the stock indexes, rather than the existence of fixed and variable rates. For example, in the case of securities in stocks form, the dealers would be able to follow the change in prices of certain companies then conclude swap contracts on the returns of those stocks that would be due at fixed terms.

[See appendix 5 Illustrative example: (securities returns swap contracts)]

\subsubsection{Commodity Swaps}

These contracts are "structured arrangements to swap fixed prices for variable ones" (Henawi, 2002). They are normally performed at times of economic instability and increased risks of higher prices.

As an example, we may state the operations that take place at times of oil prices increase, during which some countries resort to the conclusion of such contracts in order to hedge against the continuous existence of high risks, whereupon they purchase oil at a specified price during a specified period of time (Wall Street Journal, 1989). 


\section{Macrothink}

\subsection{The Legitimate Rule on Swaps}

\subsubsection{The Legitimate Rule on Interest Rate Swap Contracts}

Interest rate swaps include the selling of a fixed interest rate for a variable one, and if the interest rate is part of the swap value, i.e. not an added interest in the strict sense, the legitimate rule would be similar to the swap of a fixed value for a variable one. In addition, this swap takes place without real bartering; therefore, dealing with this type of contracts is strictly forbidden. The legitimacy of such contracts can be clarified through the following points:

- If the money swapped belongs to different issuing sides, it would be considered as a sale of a cash in hand for a postponed cash. As a result, it can be considered as a form of "Riba al-nasee'ah" (speculated interest) because of the delay and the lack of bartering.

- If the money swapped belongs to the same issuing side, this process would be considered as a sale of cash in hand for a postponed cash, enclosing asymmetry and delay. As such, it embodies a dual form of usury; i.e. riba al-nasee'ah (speculated interest) and riba al-fadl (usury of surplus).

- Moreover, the ignorance of the amount of the variable value would result in an additional increase in favor of one of the contractors at the expense of the other. In other words, interest rate swaps establish a sale relationship that decisively includes profit and loss between the contractors, resembling thus illegal gambling.

\subsubsection{The Legitimate Rule on Exchange Rate Swaps}

These contracts include the existence of two contracts in one. The first contract exchanges one currency for another in the contract assembly. Apparently, the required legal conditions of the contract are met. However, it includes a condition to establish a second contract, that is based on a reverse re-sale process with a delay of one of the compensations. In this respect, it becomes clear that this contract is forbidden for several reasons, including:

- It is a contract that includes a condition which results in another contract; hence, the prohibition of this contract on the basis of forbidding a sale on a condition. Moreover, this type intermingles, in essence, with the prohibited process of "two transactions in one" (Abu Dawood, Hadeeth N 3504).

- The first contract is an apparent contract which aims to re-sell the same currency at a later time with the delay of the compensation, which is in fact plain usury, i.e. "riba al-nasee'ah". This differs from the legal form where, in both contracts, the price combines without any increase, and the holding is done in the contract assembly without delay (Saad, 2008).

- In most cases, exchange rates swaps are conducted according to a new concept based on speculation, which aims at stimulating the exchange rates at required levels for a specific period of time. Consequently, this method includes some practices that may harm the market relations.

Islamic financial institutions use futures contracts to hedge against exchange rate fluctuations. 


\section{Macrothink Mnstitute ${ }^{m}$}

This becomes clear through the banking relationship between the Islamic financial institutions and the other financial institutions, especially in Western countries. These exchanges are based on the advisory opinions (Fatwas) of the legitimacy committees (Khan1999). In fact, some contemporary scholars have discussed the issue of currency swaps and have issued a fatwa legitimizing them on the condition that the promise to exchange foreign currencies would be fixed in terms of time and exchange rate. It should also be non-binding in order to hedge against the risks of fluctuations in foreign currencies exchange rates (Abu Gudda, 1997).

On the other hand, the currency loans between the Islamic banks and the other Western banks are different from the form of usury referred to by the scholars who state that "if it is conditioned in the loan that it should be lent by the borrower once again, it wouldn't be allowable, because the Prophet, peace be upon him, forbade simultaneous occurrence of a sale and a loan." (Ibn Qudamah, 1992). In fact, those contracts do not favor one party over the other in terms of benefit, and that the whole process is devoid of usury increase. However, the Islamic bank carries them out in order to avoid falling into such a forbidden increase, and that this process is based on mutual comparative advantages between the Islamic bank and the other party.

\subsubsection{The Legitimate Rule on Securities Returns Swaps}

The deal with securities returns swaps enter into the realm of legitimate prohibition, because the subject of the contract is the return resulting from the securities. That return is, in fact, money swapped with many violations, including:

- The value of the amount of the return is not definitively known at the conclusion of the contract, but becomes clear at maturity; therefore, these contracts may be considered as prohibited betrayal sales.

- The occurrence of both types of forbidden riba (riba al-nasee'ah and riba al-fadl) if the currencies subject of the contract share the same issuing side; and the occurrence of riba al-nasee'ah if the issuing sides are different.

- Moreover, due to the lack of parity between the interaction forces in the market, these contracts are dealt with on the basis of speculation, which is mostly in the interests of some parties at the expense of others.

- Since these contracts would definitely result in a winner or a loser, they may be considered as gambling contracts.

\subsubsection{The Legitimate Rule on Commodity Swaps}

This type of contracts is based on the swap of fixed prices for variable ones. This is the most common form in contemporary exchanges, which is not devoid of the presence of profit or loss for one of the parties at the expense of the other, resembling thus the form of contracts based on gambling.

In addition, these contracts inter in the field of ostensible sales, i.e. sales that are not meant to 
get the goods subject of the contract, but are intended to make profit from price differences. Therefore, in the absence of real exchange of goods, the prohibition in dealing with these contracts is confirmed. They are in fact a way to circumvent usury.

\section{Conclusion}

This research comes out with a set of findings and recommendations:

\subsection{The Findings}

1) Unlike in the case of sale, the option contract differs from the short selling contract in the case of purchase. In fact, investors resort to option contracts in the case of purchase when they expect higher price levels, but they would opt for a put option in case of lower price expectations. In this case, the put option would be an alternative to short-selling, and would have the same effect on price levels.

2) There is a difference between the option contracts in question and the choices contracts known in Islamic jurisprudence. Indeed, besides the fact that option contracts are derived from the capitalist system, they give the owner the right to buy or sell shares for a compensation because they represent a commodity that tolerates the existence of risk. However, choices contracts take a jurisprudential attribute, that aims at legitimizing the rights of the contractors without any compensation.

3) Holders of double option contracts would gain profits at times when the market has sudden swings in price levels. As a result, the holder of the option would pay a high reward because he anticipates an abrupt change in price. So, if the prices soar up, he will perform a call option, and if they drop, he shall implement a put option. And on the condition that his anticipations were correct, his profits would be achieved, in both cases, according to the difference between the implementation price and the market price.

4) Option contracts comprise betrayal and ignorance because the subject of the contract is neither money, nor a benefit or a financial right that may be compensated for. Besides, these contracts include corrupt clauses that violate the requisites of the contract, intermingling thus with the concept of "two transactions in one." Moreover, the corrupt condition includes a reward (bonus) which is higher than the real compensation embodying thus the concept of "forbidden usury". In addition, these contracts may be equated with gambling because of the existence of a winner and a loser.

5) Option contracts are also likened to the strictly forbidden process of "the selling of what one doesn't own," because they are fake contracts not intended for real sale. Besides, no real ownership happens through them.

6) In the case of futures contracts the allowances are delayed, which means that this type of contracts is similar to the sale of a debt for a debt, considered as one of the forbidden sales. This is applicable to all situation where futures contracts are concluded. In fact, in case the subject of the contract was gold or silver versus securities we fall in riba al-nasee'ah, for the total agreement between them in the reason for prohibition; i.e. preciousness. Moreover, futures contracts are also likened to option contracts for the fact that they intermingle with 
gambling, depend on instant speculations, and reflect the image of "selling of what is not owned."

7) As for swap contracts, they also comprise, in their various forms, the same legitimate violations as in gambling, usury, and the image of " two transactions in one," included in "exchange rate swaps."

\subsection{Recommendations}

1) The need for a legitimate database from the fatwa councils, which would help the dealers in derivatives contracts know their legitimate rule and identify any illicit activities in them. There is no doubt that there is room for more transparency to clarify the reality of these activities through the media, and the institutions of higher education, pushing, thus, towards the formation of a financial culture among those interested in this field.

2) Both the legitimate institutions and the jurisprudence academies can work together to put unified standards in the field of financial fatwa (advisory opinion). This would help in organizing the regulations and the provisions governing the investment operations in financial derivatives.

3) The authority regulating the financial market should control the investment in derivatives contracts in terms of their impact on the stability of the market, and thus make binding decisions for the preservation of social security.

4) The intervention of the governor to prevent any risk taking investments that threaten the stability of the society, and establish some fiscal and monetary policies that would be sufficient to control the movement of cash through safe financial investment channels.

5) Abiding by legitimate financial ways of investment rather than direct investment in derivatives contracts because they comprise several prohibited operations such as usury and gambling, that do not serve neither the interests of society nor the dealing parties.

6) Directing financial investments towards legitimate investment channels that would serve the interests of the various parties and achieve the dealers' objectives, whatever their views.

\section{Acknowledgement}

The research is financed by the Deanship of Scientific Research at Al-baha University, number (1434/220). Thanks for Professor Saeed Saleh Arragueeb ALGHAMEDI.

\section{References}

Abu Gudda, Abdul Sattar \& Ezzedine Khoja (1997). Al-Baraka Seminar Fatwas (1981-1997). Jeddah: Dallah Al Baraka Group.

Al-Bahooti, Mansour bin Yunus (1997). Uncovering of the mask on persuasion. Beirut: Dar Scientific Books.

Al-Qarry, Mohammed Bin Ali (1995). Financial Markets. Jeddah: Dar Hafez.

Al-Saad, Mohammed Ahmed (2008). Contemporary Financial Markets. Irbid: Dar Cultural 


\section{Macrothink}

Book.

Al-Suleiman, Mubarak Bin Sulaiman (2005). Rulings of dealing in contemporary financial markets. Riyadh: Dar Kunouz of Seville.

Awad, Marwan (1988). Foreign Currency, Investment and Finance, Theory and Practice. Oman: Institute of Banking Studies.

Balboul, Mukhtar Mohammed (1992). How to invest your money in stocks and assets. Alexandria: Modern Egyptian Office.

Dagi, Ali Mohiuddin Qara. Financial Markets in the Balance of Islamic Jurisprudence. Fiqh Council Magazine, 7.

Decision of the Islamic Fiqh Academy (1992). Seventh session, Jeddah. Resolution No. 65/6/7. Jeddah: Islamic Fiqh Academy, No. 7.

Fayyad, Attia (1998). Stock Market in the Balance of Islamic Jurisprudence. Cairo: Universities Publishing House.

Habash, Mohamed Mahmoud (1998). Global financial markets and their derivative instruments. Oman: Al-Warraq Institution.

Hamami, Abd al-Karim Qasim. Investing in Stock Options and Stock Indexes Options. Riyadh: Al-Farazdaq Commercial Printing Presses.

Hammad, Tareq Abdel Aal (2003). Financial derivatives: concepts, risk management, accounting. Academic House.

Hanafi, Abdul Ghaffar (2003). Stock Exchange. Alexandria: Dar New University.

Henawi, Mohammed Saleh \& Ibrahim Sultan Jalal Al-Abd (2002). Analysis and Evaluation of Securities. Alexandria: Acaemic House.

Ibn Al-Hammam \& Mohammed Bin Abdel Wahed. Open the Almighty. Beirut, Dar of Arab Heritage Revival.

Ibn Qudamah, Abdullah Bin Ahmad (1992). The Singer (2nd ed.). Edited by Abd Bin Abdul Mohsen Atturki. Dar Hajr.

Ibn Taymiyyah, Ahmad (1995). Entire fatwas. Ministry of Islamic Affairs, Endowments, Call and Guidance, Kingdom of Saudi Arabia.

Jack Clark (1991). Francis, Investments. New York: McGraw-Hill International Editions.

Khan, T. (1999). Hedging and Islamic Finance. A Preliminary Discussion Paper, IRTI-IDB.

Kharyoush, Hosni Ali et al. (1998). Financial Markets: Concepts and Applications. Amman: Dar Zahran.

Obaid, Saeed Tawfiq. Investing in Securities. Cairo: Ain Shams Library.

Radwan, Samir Abdel-Hamid (1996). Securities Markets (1st ed.). International Institute of 


\section{Macrothink}

Islamic Thought.

Ramadan, Ziad (1998). Principles of Real Financial Investment. Amman: Dar Wael.

Trad, Ismail (2005). Management of Foreign Operations (2nd ed.). Amman: Dar Wael.

\section{Appendix 1. Illustrative example (call option contract)}

Someone works in a Saudi company in the field of fresh fruit import and export. In winter, he bought a commodity worth a million dollars to be delivered on the usual season. On the assumption that he is known for his rational behavior, he will exchange the riyal for the dollar and keep it for the given term to meet the payments in the summer; i.e. the season of fresh fruit. For that, he decided to protect himself against the increase in the price of the dollar, so he bought a "Call option" contract for one million dollars for four months, at the current exchange rate of (3.75) SR / USD, for a reward paid to the option editor equal to 10 thousand dollars.

In the case the price of the dollar goes up to (3.8) SR/USD, he will purchase at the implementation price, and achieve profit in the following way:

Purchase value $=$ implementation price $\times$ quantity $=3.75 \times 1000000=3750000$ SR

The costs $=$ purchase value + bonus $=3750000+10000=3760000 \mathrm{SR}$

The sold value $=$ prevailing price $\times$ quantity $=3.8 \times 1000000=3800000 \mathrm{SR}$

The Profit $=$ sold value - cost $=3800000-3760000=40,000$ SR

In the case the price of the dollar goes down to (3.7) SR/USD, the loss shall be according to the following equation:

$$
\begin{aligned}
\text { Loss } & =\text { sold value }- \text { costs } \\
& =(\text { Prevailing price } \times \text { quantity })-[(\text { implementation price } \times \text { quantity })+\text { bonus }] \\
& =(3.7 \times 1000000)-[(3.75 \times 1000000)+10000] \\
& =3700000-[3750000+10,000] \\
& =3700000-3760000 \\
& =-60,000 \mathrm{SR} .
\end{aligned}
$$

It is clear that the (5\%) change in exchange rate will have an impact in the case of loss greater than that in the case of profit, because the reward, which is an additional component of the costs, is added to it. Generally, the investor will not, in the case of low exchange rate, import according to the prevailing price (3.7), because he is characterized by a rational behavior; he will, on the contrary, import at the implementation price; i.e. (3.75) SR /USD. 


\section{Appendix 2. Illustrative example (futures contracts)}

The investor (X) trades in fixed income securities (bonds), so he bought bonds of a market value equal to one million riyals for only (800) thousand riyals; and due to interest rate fluctuations and the expectations of a rise and then a drop in the price of the bonds, he concluded a futures contract to sell those bonds for (795) thousand riyals to be handed over after three months. However, by the time the handover was due, the market value of the bonds decreased to (790) thousand riyals. Moreover, the value of the bonds in the futures contracts market dropped to (780) thousand riyals. And based on these changes, the equation of gains and losses will be as following:

Loss in normal market $=$ change in market value $=800-790=10$ thousand riyals .

Profit in futures contracts market $=$ change of value in futures contracts market

$=795-780=15$ thousand riyals.

Net profit $=$ Profit - Loss $=15-10=5$ thousand riyals.

\section{Appendix 3. Illustrative Example (interest rate swaps)}

Both the financial institution (x) and the financial institution (y) agreed to swap a fixed interest rate for a variable for a period of 10 years. The agreement stated that the institution (x), which expected high interest rates, would pay a fixed interest rate of $3 \%$ on the value of a swap contract equivalent to ten million riyals, while the institution (y) would pay a variable interest rate of $5 \%$ based on the prevailing market price for each quarter of the year. This sort of agreement can be mathematically portrayed as following:

Commitment of the financial institution $(x)=$ percentage of the fixed interest $x$ the sum $x$ quarter of the year

$$
=3 \% \times 10000000 \times(90 / 360)=75000 \mathrm{SR}
$$

Commitment of the financial institution $(y)=$ percentage of the variable interest $\times$ the sum $\times$ quarter of the year

$$
=5 \% \times 10000000 \times(90 / 360)=125000 \mathrm{SR}
$$

Loss of the institution $(\mathrm{y})=$ the change between the two commitments

$$
=125000-75000=50000 \mathrm{SR}
$$

This means that the institution (y) would be committed to a loss if: the percentage of the variable interest rate $>$ the percentage of the fixed interest rate

Whereas it would gain expected profit if: the percentage of the variable interest rate $<$ the percentage of the fixed interest rate 


\section{Appendix 4. Illustrative example (foreign currency swaps)}

We can illustrate this type of swaps by the existence of two parties: The first party (x) who works in the export of petrochemicals in Saudi Arabia; the second party (y) and works in America in the field of technology export. If we assume that $(\mathrm{x})$ has ten million riyals, which he does not need at the moment, because of debt obligations equivalent to that sum in dollar, and (y) has the same value in dollar, which he also does not need at the present time because of debt obligations equivalent to it in Riyal. And assuming that both (x) and (y) are known for their rational behavior, they would sign a currency swap contract that involves the riyal and the dollar, and determines the forward rate for each of the two currencies. Therefore, it becomes clear that both (x) and (y) have simply achieved the type of currency immediately needed, the quantity required, and the forward rate desired, saving thus any expected increase in the costs that may result from either the variation of exchange rates, or the borrowing from the banking system at an interest rate.

\section{Appendix 5. Illustrative example (securities returns swap contracts}

To clarify this case we consider two parties; the first party (x) has enough experience in the movement of the share of the electricity company in the Saudi financial market; whereas the second party (y) has enough experience in the movement of the share of Savola in the same market. Both (x) and (y) agreed to conclude a securities returns swap (shares) equal to the value of one million riyals, and that the returns of this swap would be due in two months.

In the case of an increase in the return rate of the electricity share to $3 \%$ and that of Savola to $5 \%$, the swap can be mathematically represented as following:

Commitment of the party $(\mathrm{x})=3 \% \times 1000000=30000 \mathrm{SR}$

Commitment of the party $(y)=5 \% \times 1000000=50000$ SR

Loss of the party $(y)=$ the change between the two commitments

$$
=50000-30000=20000 \mathrm{SR}
$$

It is clear that in case the return rate between both shares changes, only one of the parties would achieve a profit at the expense of the other, regardless of the direction of the change whether descending or ascending.

\section{Copyright Disclaimer}

Copyright reserved by the author(s).

This article is an open-access article distributed under the terms and conditions of the Creative Commons Attribution license (http://creativecommons.org/licenses/by/3.0/). 